\title{
Carbon Storage in Sediments of Freshwater Fishponds of Odisha, Andhra Pradesh, and West Bengal, India
}

\author{
Adhikari S'*, Mahanty D1, Ikmail S², Sarkar S², \\ Rathod $\mathbf{R}^{3}$ and Pillai BR ${ }^{2}$ \\ ${ }^{1}$ Regional Research Centre (RRC) of ICAR-Central \\ Institute of Freshwater Aquaculture, West Bengal, India \\ ${ }^{2}$ ICAR-Central Institute of Freshwater Aquaculture, India \\ ${ }^{3}$ Regional Research Centre (RRC) of ICAR-CIFA, \\ Penamaluru Fish Seed Farm, India \\ *Correspondling author: Subhendu Adhikari, Regional \\ Research Centre (RRC) of ICAR-Central Institute of \\ Freshwater Aquaculture, Rahara, Kolkata, West Bengal, \\ India
}

Received: September 27, 2019; Accepted: October 29, 2019; Published: November 05, 2019

\begin{abstract}
Considering the impact of climate change on aquaculture practices, carbon storage by fish pond sediment could mitigate some emission of greenhouse gases form the fish ponds. The potentials of carbon storage by the sediments of fish ponds of Ganjam, Keonjhargarh, and Puri districts of Odisha, Krishna district of Andhra Pradesh, Moyna and Tamluk of East Medinipur, Purulia, Bankura, Murshidabad, South and North 24 Parganas districts of West Bengal, India were estimated. It is evident from the results that with an increase in fish production, the $\mathrm{C}$ storage decreased. The production per crop in the present study increased from $1815 \pm 376 \mathrm{~kg} / \mathrm{ha}$ to $8351 \pm 1882 \mathrm{~kg} / \mathrm{ha}$ and accordingly, the $C$ storage $/ \mathrm{kg}$ fish decreased from $1.44 \pm 0.73$ to $0.62 \pm 0.21$. The three types of combined humus carbon (loosely, stably and tightly combined humus carbon) were also analyzed for some sediment in the present study. The loosely combined humus varied from 36 to 43 per cent, stably combined humus varied from 4 to 6 per cent, and tightly combined humus varied from 53 to 58 per cent, respectively. Among the three combined humus, loosely combined form constitute about 40 percent of the total soil organic carbon, and thus, carbon sequestration could be 60 percent of the total soil carbon storage.
\end{abstract}

Keywords: Carbon storage; Sequestration; Sediments; Aquaculture ponds

\section{Introduction}

Increase in greenhouse gases (GHGs) concentration in the atmosphere is the main reason for climate change as accumulated GHGs in the atmosphere intercepts outgoing infra-red radiation which traps heat and raises the temperature in the atmosphere. The carbon dioxide $\left(\mathrm{CO}_{2}\right)$ level has increased by 31 per cent, from $280 \mathrm{ppmv}$ in 1850 to $380 \mathrm{ppmv}$ in 2005, and is now increasing at $1.7 \mathrm{ppmv} / \mathrm{yr}$ [1]. With this increase, there is a growing public and scientific concern about the carbon sequestration potential of various terrestrial ecosystems especially wetlands [2]. It has been suggested that the sequestration of atmospheric $\mathrm{CO}_{2}$ into soil organic carbon (SOC) could contribute significantly to adhere with the Kyoto Protocol to reduce emissions of greenhouse gases [3,4]. In stabilizing the atmospheric abundance of $\mathrm{CO}_{2}$ and other greenhouse gases to mitigate the risks of global warming [5]. [6] suggested that there are three strategies of lowering $\mathrm{CO}_{2}$ emissions: (i) reducing the global energy use, (ii) developing low or no-carbon fuel, and (iii) sequestering $\mathrm{CO}_{2}$ from point sources or atmosphere through natural and engineering techniques. Fifteen options of stabilizing the atmospheric concentration of $\mathrm{CO}_{2}$ by 2050 at approximately 550 $\mathrm{ppm}$ have been outlined by [7]. Three of these 15 options were based on carbon sequestration in terrestrial ecosystems [8]. In this respect, aquaculture ponds can play potential role in carbon sequestration.

During the last three decades world food fish production of aquaculture has expanded by almost 12 times, with an average annual rate of 8.8 per cent. Presently 600 aquatic species are raised in captivity in about 190 countries for production in farming systems of varying input intensities and technological sophistication (FAO, 2016). Thus, there is immense scope to store and capture carbon by the fishponds to reduce and offset the chance of emitting different GHGs from the different aquaculture systems. Thus the objectives of the present study are: (i) to assess the potentials of carbon storage in different aquaculture ponds of three different states in India; (ii) to determine the extent of carbon sequestration of pond sediments.

\section{Materials and Methods}

Aquaculture ponds were chosen for the carbon storage study from the Ganjam $\left(19.5860^{\circ} \mathrm{N}, 84.6897^{\circ} \mathrm{E}\right)$, Keonjhargarh $\left(21.6289^{\circ}\right.$ $\left.\mathrm{N}, 85.5817^{\circ} \mathrm{E}\right)$ and Puri $\left(19.8134^{\circ} \mathrm{N}, 85.8315^{\circ} \mathrm{E}\right)$ districts of Odisha, Kaikaluru Mandal $\left(16.5527^{\circ} \mathrm{N}, 81.2129^{\circ} \mathrm{E}\right)$ of Krishna district of Andhra Pradesh, and Moyna $\left(22.2738^{\circ} \mathrm{N}, 87.7697^{\circ} \mathrm{E}\right)$, Tamluk block $\left(22.2788^{\circ} \mathrm{N}, 87.9188^{\circ} \mathrm{E}\right)$ of East Medinipur, Purulia $\left(23.3321^{\circ}\right.$ $\left.\mathrm{N}, 86.3652^{\circ} \mathrm{E}\right)$, Bankura $\left(23.1645^{\circ} \mathrm{N}, 87.0624^{\circ} \mathrm{E}\right)$, Murshidabad $\left(24.2290^{\circ} \mathrm{N}, 88.2461^{\circ} \mathrm{E}\right)$, south 24 Parganas $\left(22.1352^{\circ} \mathrm{N}, 88.4016^{\circ}\right.$ E) and North 24 Parganas $\left(22.6168^{\circ} \mathrm{N}, 88.4029^{\circ} \mathrm{E}\right)$ districts of West Bengal, India. Overall, the culture period in these areas varied from 180 to 300 days. The culture practices in these ponds are shown in Table 1.

\section{Calculation of carbon storage}

Soil carbon storage was measured by CORE Method. In this method, sediment samples from the pond was collected by a soil sampler (Corer) in such a way that only the sediment core was collected, no bottom soil below the sediment was collected. The sediment dry bulk density was measured and the sediment organic carbon was determined by $\mathrm{CHN}$ Analyzer. The carbon storage $(\mathrm{Mg}$ $\mathrm{C} / \mathrm{ha}$, mega gram $\mathrm{C} / \mathrm{ha}$ ) was calculated as per [9] as follows $=[\mathrm{C}$ $(\%)^{\star}$ dry bulk density $\left(\mathrm{Mg} / \mathrm{m}^{3}\right)^{\star}$ depth $\left.(\mathrm{m})^{\star} 10^{4} \mathrm{~m}^{2}\right] / 100$. 
Table 1: Culture practices in the ponds under different places under study.

\begin{tabular}{|c|c|c|c|c|}
\hline Area/Location & $\begin{array}{l}\text { Culture of } \\
\text { Species with } \\
\text { Stocking size }(g)\end{array}$ & $\begin{array}{l}\text { Stocking density } \\
\left(10^{3 / h a}\right)\end{array}$ & $\begin{array}{l}\text { Harvesting size } \\
\qquad(\mathrm{g})\end{array}$ & Management practices \\
\hline $\begin{array}{l}\text { Ganjam, Puri, Keonjhargarh, } \\
\text { Puri, Odisha }\end{array}$ & $\begin{array}{l}\text { Rohu }(5.0-8.0) \\
\text { Catla }(5.0-8.0) \\
\text { Mrigal }(5.0-8.0)\end{array}$ & 5.0 & $\begin{array}{l}\text { Rohu } 700 \\
\text { Catla } 900 \\
\text { Mrigal } 500\end{array}$ & $\begin{array}{l}\text { Organic manure (cow dung), Inorganic fertilizers (Urea,Single Super } \\
\text { Phosphate), lime. Supplementary feeding with ground nut oil cake and rice } \\
\text { bran in a ratio of 1:1. }\end{array}$ \\
\hline $\begin{array}{l}\text { Kaikaloru, Krishna, Andhra } \\
\text { Pradesh }\end{array}$ & $\begin{array}{l}\text { Rohu- } 50 \\
\text { Catla } 150 \\
\text { Mrigal } 100\end{array}$ & 5.0 & $\begin{array}{l}\text { Rohu } 1100 \\
\text { Catla } 2200 \\
\text { Mrigal } 1300\end{array}$ & $\begin{array}{l}\text { Mainly pelleted feed along with organic manure (cow dung), inorganic } \\
\text { fertilizers, lime. }\end{array}$ \\
\hline $\begin{array}{l}\text { Moyna , } \\
\text { West Bengal }\end{array}$ & $\begin{array}{l}\text { Rohu- } 90 \\
\text { Catla } 110 \\
\text { Mrigal } 70\end{array}$ & $\begin{array}{l}5.0-14.0 \\
\text { (av. } 10.0)\end{array}$ & $\begin{array}{l}\text { Rohu } 800 \\
\text { Catla } 1200 \\
\text { Mrigal } 600\end{array}$ & Mainly pelleted feed along with inorganic fertilizers, lime. \\
\hline Tamluk, West Bengal & $\begin{array}{l}\text { Rohu- 50-100 } \\
\quad(\text { av.70) } \\
\text { Catla 75-200 } \\
\quad \text { (av.120) } \\
\text { Mrigal 25-150 } \\
\quad \text { (av.70) }\end{array}$ & 5.0-14.0 (av.9.0) & $\begin{array}{l}\text { Rohu } 770 \\
\text { Catla } 1170 \\
\text { Mrigal } 600\end{array}$ & $\begin{array}{l}\text { Mainly pelleted feed along with organic manure (cow dung), inorganic } \\
\text { fertilizers, lime. }\end{array}$ \\
\hline Bankura, West Bengal & $\begin{array}{c}\text { Rohu- } 20 \\
\text { Catla } 25 \\
\text { Mrigal } 18\end{array}$ & 5.0- 7.0 (av.6.0) & $\begin{array}{l}\text { Rohu } 460 \\
\text { Catla } 1000 \\
\text { Mrigal } 425\end{array}$ & $\begin{array}{l}\text { Mainly pelleted feed along with organic manure (cow dung), inorganic } \\
\text { fertilizers, lime. }\end{array}$ \\
\hline Murshidabad, West Bengal & $\begin{array}{l}\text { Rohu- } 80 \\
\text { Catla } 130 \\
\text { Mrigal } 60\end{array}$ & $2.5-7.5$ (av.5.8) & $\begin{array}{l}\text { Rohu } 775 \\
\text { Catla } 1600 \\
\text { Mrigal } 650\end{array}$ & $\begin{array}{l}\text { Mainly pelleted feed along with organic manure (cow dung), inorganic } \\
\text { fertilizers, lime. }\end{array}$ \\
\hline $\begin{array}{l}\text { North and South } 24 \\
\text { Parganas, } \\
\text { West Bengal }\end{array}$ & $\begin{array}{l}\text { Rohu- } 100 \\
\text { Catla } 500 \\
\text { Mrigal } 50\end{array}$ & $\begin{array}{l}6.6-11.2 \\
(\text { av.9.0) }\end{array}$ & $\begin{array}{l}\text { Rohu } 900 \\
\text { Catla } 2800 \\
\text { Mrigal } 600\end{array}$ & $\begin{array}{l}\text { Mainly pelleted feed along with organic manure (cow dung), inorganic } \\
\text { fertilizers, lime. }\end{array}$ \\
\hline
\end{tabular}

Table 2: Sediment carbon storage in fish ponds of Ganjam district of Odisha.

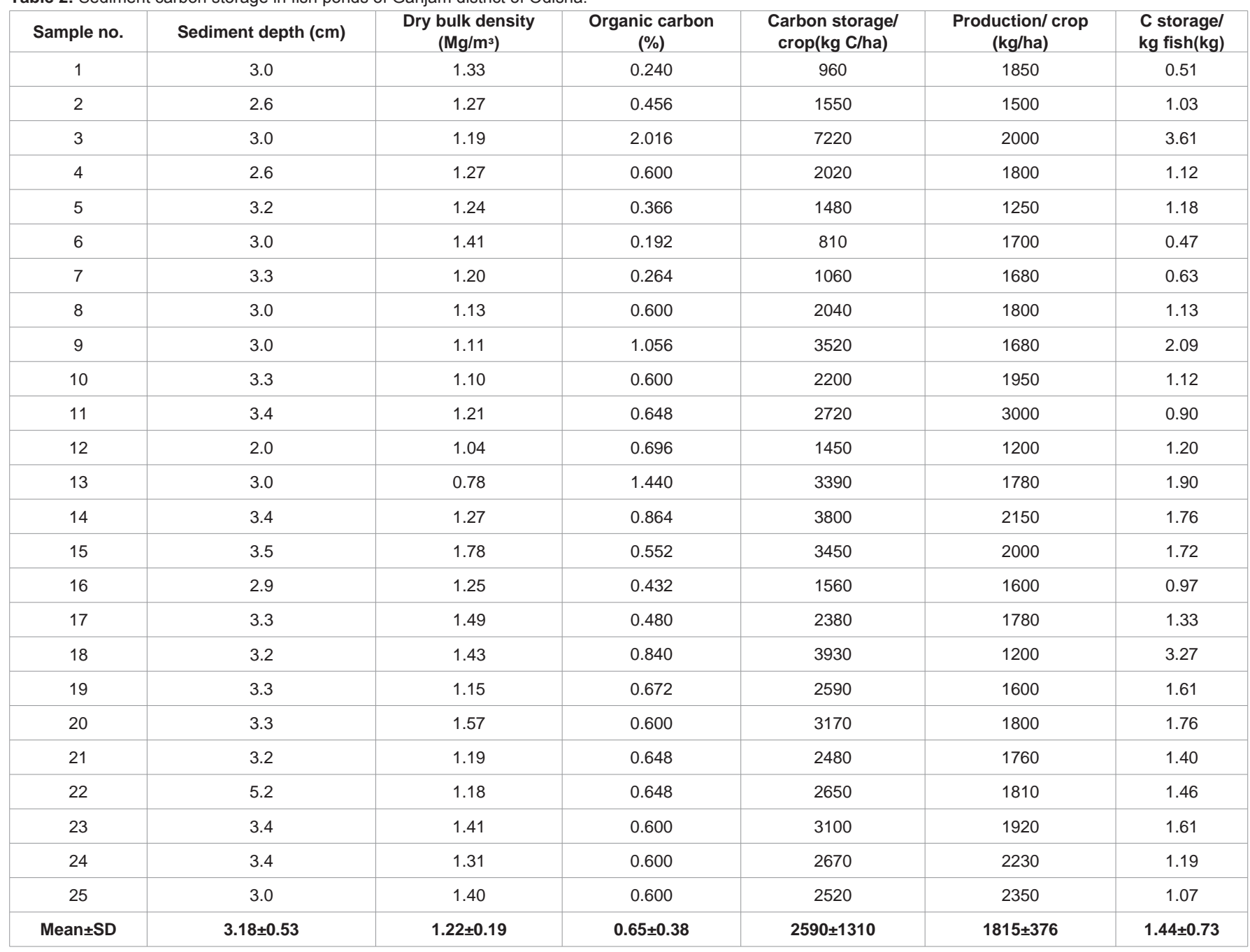


Table 3: Sediment carbon storage in fish ponds of Keonjhargarh district of Odisha.

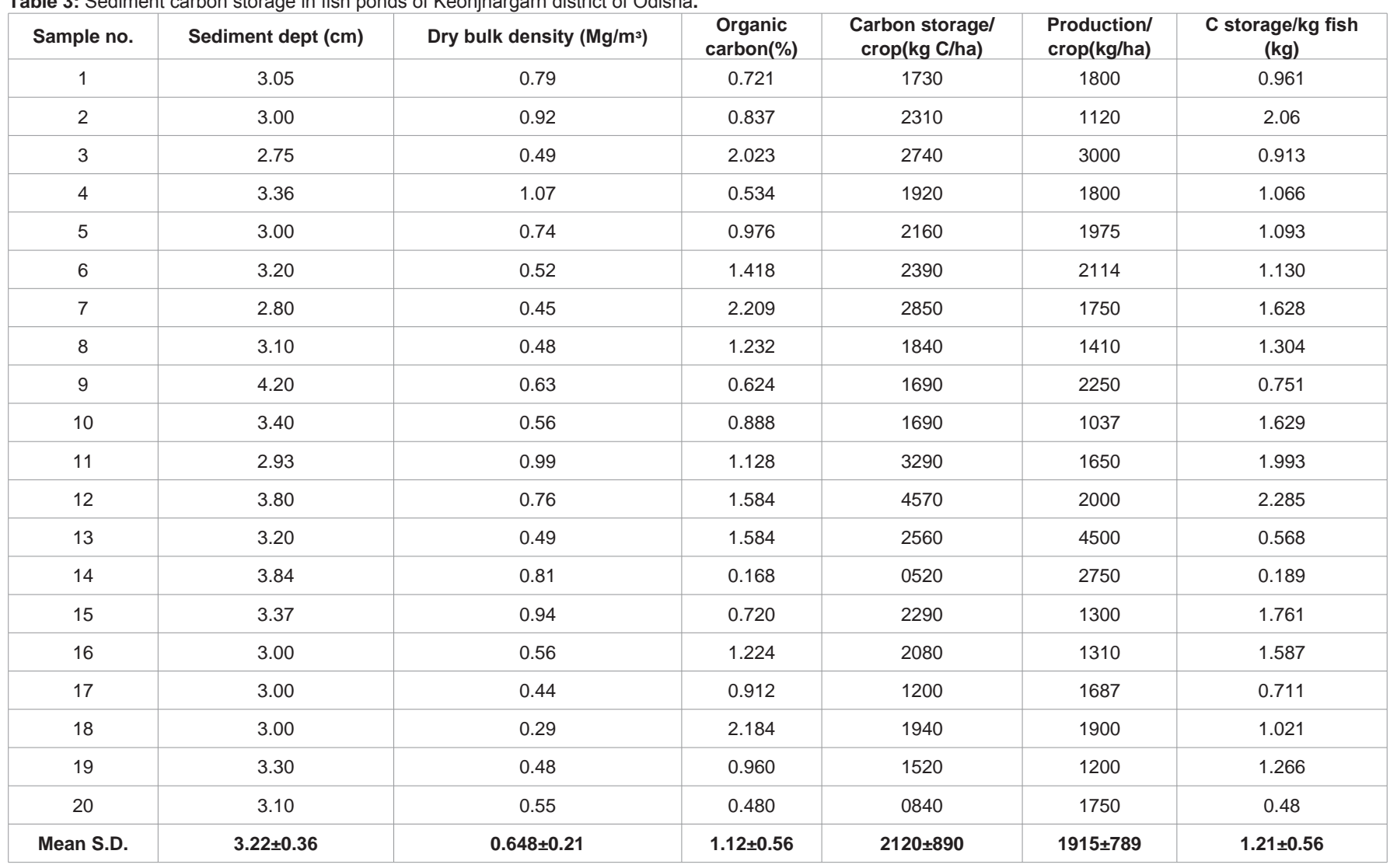

\section{Analysis of combined humus forms}

The combined humus forms are classified into three types by using three different extractants and were extracted as: (i) the loosely combined humus was extracted using $0.1 \mathrm{M} \mathrm{NaOH}$; (ii) the stably combined humus was extracted using $0.1 \mathrm{M} \mathrm{N}_{\mathrm{a}} 4 \mathrm{P}_{2} \mathrm{O}_{7}+0.1 \mathrm{M} \mathrm{NaOH}$ mixed liquid ( $\mathrm{pH} \mathrm{13)}$; and (iii) the residue was considered as the tightly combined humus. Both of the loosely and stably combined humus solution was measured at 465 and $665 \mathrm{~nm}$ using the ultraviolet spectrophotometer, respectively [10]. The E465/E665 ratio was calculated by dividing the absorbance of the sample at $465 \mathrm{~nm}$ by that at $665 \mathrm{~nm}$. The loosely and stably combined humus $\mathrm{C}$ contents were measured by a liquid $\mathrm{C} / \mathrm{N}$ analyzer, whereas the tightly combined humus $\mathrm{C}$ content was calculated by subtracting the sum of the loosely and stably combined humus $\mathrm{C}$ contents from the total humus $\mathrm{C}$ content [10]. (SD).

All the data were presented as average with standard deviation

\section{Results and Discussion}

The sediment carbon storage in fish ponds of Ganjam district of Odisha is presented in Table 2. The organic carbon and carbon storage in the sediments of the fish ponds were $0.65 \pm 0.38$ per cent and $2590 \pm 1310 \mathrm{~kg} \mathrm{C} / \mathrm{ha} / \mathrm{crop}$, respectively. The fish production was $1815 \pm 376 \mathrm{~kg} / \mathrm{ha} / \mathrm{crop}$. The C storage was $1.44 \pm 0.73 \mathrm{~kg} / \mathrm{kg}$ fish.

The sediment carbon storage in fish ponds of Keionjhargarh district of Odisha is presented in Table 3. The organic carbon and carbon storage in the sediments of the fish ponds were $1.12 \pm 0.56$ per cent and $2120 \pm 890 \mathrm{~kg} \mathrm{C} / \mathrm{ha} / \mathrm{crop}$, respectively. The fish production was $1915 \pm 789 \mathrm{~kg} / \mathrm{ha} / \mathrm{crop}$. The C storage was $1.21 \pm 0.56 \mathrm{~kg} / \mathrm{kg}$ fish.

The sediment carbon storage in fish ponds of Puri district of Odisha is presented in Table 4. The organic carbon and carbon storage in the sediments of the fish ponds were $0.66 \pm 0.37$ per cent and $2340 \pm 1470 \mathrm{~kg} \mathrm{C} / \mathrm{ha} / \mathrm{crop}$, respectively. The fish production was $2044 \pm 1118 \mathrm{~kg} / \mathrm{ha} / \mathrm{crop}$. The C storage was $1.64 \pm 1.24 \mathrm{~kg} / \mathrm{kg}$ fish.

The sediment carbon storage in fish ponds of Kaikaluru, Krishna district of Andhra Pradesh is shown in Table 5. The organic carbon content in the sediments was $1.5 \pm 0.68$ per cent, and the carbon storage was $5486 \pm 2980 \mathrm{~kg} \mathrm{C} / \mathrm{ha} / \mathrm{crop}$. The fish production was $8351 \pm 1882 \mathrm{~kg} /$ ha/crop. The C storage was $0.62 \pm 0.21 \mathrm{~kg} / \mathrm{kg}$ fish.

The sediment carbon storage in fish ponds of Moyna, East Medinipur district of West Bengal is shown in Table 6. The organic carbon content in the sediments was $1.35 \pm 0.65$ per cent, and the carbon storage was $5682 \pm 1591 \mathrm{~kg} \mathrm{C} / \mathrm{ha} / \mathrm{crop}$. The fish production was $7475 \pm 1156 \mathrm{~kg} / \mathrm{ha} / \mathrm{crop}$. The C storage was $0.76 \pm 0.19 \mathrm{~kg} / \mathrm{kg}$ fish.

The sediment carbon storage in fish ponds of Tamluk, East Medinipur district of West Bengal is presented in Table 7. The organic carbon and carbon storage in the sediments of the fish ponds were $1.42 \pm 0.63$ per cent and $5490 \pm 2336 \mathrm{~kg} \mathrm{C} / \mathrm{ha} / \mathrm{crop}$, respectively. The fish production was $7169 \pm 3065 \mathrm{~kg} / \mathrm{ha} / \mathrm{crop}$. The $\mathrm{C}$ storage was $1.80 \pm 0.30 \mathrm{~kg} / \mathrm{kg}$ fish.

The sediment carbon storage in fish ponds of Purulia district of West Bengal is presented in Table 8. The organic carbon and carbon storage in the sediments of the fish ponds were $1.08 \pm 0.33$ per cent 
Table 4: Sediment carbon storage in fish ponds of Puri district of Odisha.

\begin{tabular}{|c|c|c|c|c|c|c|}
\hline Sample no. & Sediment level (cm) & $\begin{array}{l}\text { Dry bulk density } \\
\qquad\left(\mathrm{Mg} / \mathrm{m}^{3}\right)\end{array}$ & $\begin{array}{c}\text { Organic carbon } \\
(\%)\end{array}$ & $\begin{array}{c}\text { Carbon storage } \\
\text { /crop } \\
\text { (kg/ha) }\end{array}$ & $\begin{array}{l}\text { Production/ crop } \\
\text { (kg/ha) }\end{array}$ & $\begin{array}{c}\text { C storage/ kg fish } \\
(\mathbf{k g})\end{array}$ \\
\hline 1 & 2.3 & 2.84 & 0.227 & 1480 & 1250 & 1.184 \\
\hline 2 & 3.7 & 0.84 & 0.954 & 3030 & 2500 & 1.212 \\
\hline 3 & 2.45 & 1.25 & 0.500 & 1530 & 1500 & 1.02 \\
\hline 4 & 1.95 & 2.67 & 0.410 & 2130 & 1000 & 2.13 \\
\hline 5 & 2.33 & 1.10 & 0.250 & 0640 & 1000 & 0.64 \\
\hline 6 & 3.3 & 1.02 & 0.886 & 3000 & 880 & 3.40 \\
\hline 7 & 2.0 & 2.07 & 1.364 & 5670 & 3800 & 1.49 \\
\hline 8 & 3.2 & 1.60 & 0.250 & 1280 & 1154 & 1.109 \\
\hline 9 & 2.75 & 0.55 & 0.636 & 0960 & 2130 & 0.450 \\
\hline 10 & 3.5 & 1.12 & 1.023 & 4040 & 875 & 4.617 \\
\hline 12 & 3.5 & 1.18 & 0.515 & 2130 & 3500 & 0.608 \\
\hline 13 & 5.2 & 0.47 & 0.425 & 1040 & 3750 & 0.277 \\
\hline 14 & 3.24 & 0.80 & 0.672 & 1760 & 1375 & 1.28 \\
\hline 15 & 2.99 & 2.23 & 1.454 & 9730 & 3800 & 2.56 \\
\hline 16 & 3.33 & 1.3 & 1.068 & 4730 & 1250 & 3.78 \\
\hline 17 & 3.25 & 1.10 & 0.492 & 1770 & 2000 & 0.885 \\
\hline Mean $\pm S D$ & $3.07 \pm 0.83$ & $1.523 \pm 0.80$ & $0.660 \pm 0.37$ & $2340 \pm 1470$ & $2044 \pm 1118$ & $1.64 \pm 1.24$ \\
\hline
\end{tabular}

Table 5: Sediment carbon storage in fish ponds of Kaikaluru, Krishna district of Andhra Pradesh.

\begin{tabular}{|c|c|c|c|c|c|c|}
\hline Sample no. & Sediment dept (cm) & Dry bulk density $\left(\mathrm{Mg} / \mathrm{m}^{3}\right)$ & $\begin{array}{c}\text { Organic } \\
\text { carbon } \\
(\%)\end{array}$ & $\begin{array}{c}\text { Carbon storagel } \\
\text { crop } \\
(\mathrm{kg} / \mathrm{ha})\end{array}$ & $\begin{array}{c}\text { Production/ } \\
\text { Crop } \\
\text { (kg/ha) }\end{array}$ & $\begin{array}{c}\text { C storage/ kg fish } \\
(\mathrm{kg})\end{array}$ \\
\hline 1 & 6.85 & 0.88 & 0.92 & 5550 & 8500 & 0.65 \\
\hline 2 & 6.92 & 0.60 & 2.53 & 10500 & 10,666 & 0.98 \\
\hline 3 & 6.92 & 0.30 & 2.07 & 4290 & 8000 & 0.53 \\
\hline 4 & 6.66 & 0.39 & 1.01 & 2680 & 5500 & 0.48 \\
\hline 5 & 6.15 & 0.74 & 0.97 & 4410 & 9090 & 0.48 \\
\hline Mean $\pm S . D$ & $6.7 \pm 0.32$ & $0.582 \pm 0.24$ & $1.5 \pm 0.68$ & $5486 \pm 2980$ & $8351 \pm 1882$ & $0.62 \pm 0.21$ \\
\hline
\end{tabular}

Table 6: Sediment carbon storage in fish ponds of Moyna, East Medinipur district of West Bengal.

\begin{tabular}{|c|c|c|c|c|c|c|}
\hline Sample no. & Sediment level (cm) & $\begin{array}{l}\text { Dry bulk density } \\
\qquad\left(\mathrm{Mg} / \mathrm{m}^{3}\right)\end{array}$ & Organic carbon (\%) & $\begin{array}{c}\text { Carbon storagel } \\
\text { Crop } \\
\text { (kg/ha) }\end{array}$ & $\begin{array}{c}\text { Production/ } \\
\text { crop } \\
\text { (kg/ha) }\end{array}$ & $\begin{array}{c}\text { C storage/ kg fish } \\
(\mathbf{k g})\end{array}$ \\
\hline 1 & 5.0 & 0.59 & 1.38 & 4071 & 8000 & 0.50 \\
\hline 2 & 7.9 & 1.01 & 0.66 & 5266 & 6500 & 0.81 \\
\hline 3 & 6.3 & 0.56 & 1.41 & 4974 & 5800 & 0.85 \\
\hline 4 & 4.8 & 1.07 & 1.51 & 7755 & 9000 & 0.86 \\
\hline 6 & 6.4 & 0.98 & 0.71 & 4453 & 8050 & 0.55 \\
\hline Mean $\pm S . D$ & $5.93 \pm 1.17$ & $0.80 \pm 0.24$ & $1.35 \pm 0.65$ & $5682 \pm 1591$ & $7475 \pm 1156$ & $0.76 \pm 0.19$ \\
\hline
\end{tabular}

and $3217 \pm 818 \mathrm{~kg} \mathrm{C} / \mathrm{ha} / \mathrm{crop}$, respectively. The fish production was $2363 \pm 813 \mathrm{~kg} / \mathrm{ha} / \mathrm{crop}$. The C storage was $1.43 \pm 0.39 \mathrm{~kg} / \mathrm{kg}$ fish.

The sediment carbon storage in fish ponds of Bankura district of West Bengal is shown in Table 9. The organic carbon content in the sediments was $1.52 \pm 0.81$ per cent, and the carbon storage was $4708 \pm 3248 \mathrm{~kg} \mathrm{C} / \mathrm{ha} / \mathrm{crop}$. The fish production was $4326 \pm 1441 \mathrm{~kg} / \mathrm{ha} /$ crop. The C storage was $1.15 \pm 0.67 \mathrm{~kg} / \mathrm{kg}$ fish.
The sediment carbon storage in fish ponds of Murshidabad districts of West Bengal is shown in Table 10. The organic carbon content in the sediments of fish ponds was $1.18 \pm 0.40$ per cent, and the carbon storage was $5210 \pm 910 \mathrm{~kg} \mathrm{C} / \mathrm{ha} / \mathrm{crop}$. The fish production was $6375 \pm 1932 \mathrm{~kg} / \mathrm{ha} / \mathrm{crop}$, and the $\mathrm{C}$ storage was $0.87 \pm 0.30 \mathrm{~kg} / \mathrm{kg}$ fish in the fish ponds of Murshidabad district.

The sediment carbon storage in fish ponds of South and North 24 
Table 7: Sediment carbon storage in fish ponds of Tamluk, East Medinipur district of West Bengal.

\begin{tabular}{|c|c|c|c|c|c|c|}
\hline Sample no. & $\begin{array}{c}\text { Sediment level } \\
(\mathrm{cm})\end{array}$ & $\begin{array}{l}\text { Dry bulk density } \\
\left(\mathrm{Mg} / \mathrm{m}^{3}\right)\end{array}$ & Organic carbon (\%) & $\begin{array}{l}\text { Carbon storagel } \\
\text { crop(kg/ha) }\end{array}$ & $\begin{array}{l}\text { Production/ } \\
\text { crop (kg/ha) }\end{array}$ & $\begin{array}{c}\text { C storage/ kg fish } \\
(\mathrm{kg})\end{array}$ \\
\hline 1 & 5 & 0.78 & 0.66 & 2574 & 6633 & 0.38 \\
\hline 2 & 5 & 0.73 & 1.02 & 3723 & 4300 & 0.86 \\
\hline 3 & 5 & 0.55 & 1.38 & 3795 & 6600 & 0.57 \\
\hline 4 & 6 & 1.01 & 1.65 & 9999 & 6795 & 1.47 \\
\hline 5 & 5 & 0.61 & 2.35 & 7167 & 10,000 & 0.71 \\
\hline 6 & 5 & 0.58 & 2.47 & 7163 & 14,400 & 0.49 \\
\hline 7 & 6 & 0.76 & 0.91 & 4149 & 4100 & 1.01 \\
\hline 8 & 6 & 0.88 & 0.83 & 4382 & 5750 & 0.76 \\
\hline 9 & 6 & 0.65 & 1.12 & 4368 & 5313 & 0.82 \\
\hline 10 & 5 & 0.82 & 1.85 & 7585 & 7800 & 0.97 \\
\hline
\end{tabular}

Table 8: Sediment carbon storage in fish ponds of Purulia district of West Bengal.

\begin{tabular}{|c|c|c|c|c|c|c|}
\hline Sample no. & Sediment level (cm) & $\begin{array}{l}\text { Dry bulk density } \\
\qquad\left(\mathrm{Mg} / \mathrm{m}^{3}\right)\end{array}$ & Organic carbon (\%) & $\begin{array}{c}\text { Carbon storagel } \\
\text { crop } \\
\text { (kg/ha) }\end{array}$ & $\begin{array}{c}\text { Production/ } \\
\text { crop } \\
\text { (kg/ha) }\end{array}$ & $\begin{array}{c}\text { C storage/ kg fish } \\
(\mathrm{kg})\end{array}$ \\
\hline 1 & 4.2 & 0.99 & 0.68 & 2827 & 1687 & 1.67 \\
\hline 2 & 2.7 & 1.17 & 1.39 & 4391 & 3376 & 1.30 \\
\hline 3 & 3.0 & 1.23 & 0.97 & 3579 & 1700 & 2.10 \\
\hline 4 & 2.7 & 0.77 & 1.47 & 3056 & 1880 & 1.62 \\
\hline 5 & 5.0 & 0.62 & 0.71 & 2201 & 1716 & 1.28 \\
\hline 6 & 5.5 & 0.45 & 0.98 & 2425 & 2683 & 0.90 \\
\hline 7 & 3.7 & 0.78 & 1.4 & 4040 & 3500 & 1.15 \\
\hline Mean $\pm S . D$ & $3.82 \pm 1.12$ & $0.85 \pm 0.28$ & $1.08 \pm 0.33$ & $3217 \pm 818$ & $2363 \pm 813$ & $1.43 \pm 0.39$ \\
\hline
\end{tabular}

Table 9: Sediment carbon storage in fish ponds of Bankura district of West Bengal.

\begin{tabular}{|c|c|c|c|c|c|c|}
\hline Sample no. & Sediment level $(\mathrm{cm})$ & $\begin{array}{l}\text { Dry bulk density } \\
\qquad\left(\mathrm{Mg} / \mathrm{m}^{3}\right)\end{array}$ & Organic carbon (\%) & $\begin{array}{c}\text { Carbon storagel } \\
\text { crop } \\
(\mathrm{kg} / \mathrm{ha})\end{array}$ & $\begin{array}{c}\text { Production/ } \\
\text { crop } \\
\text { (kg/ha) }\end{array}$ & $\begin{array}{c}\text { C storage/ kg fish } \\
(\mathrm{kg})\end{array}$ \\
\hline 1 & 3.0 & 0.93 & 2.4 & 6696 & 3800 & 1.76 \\
\hline 2 & 5.0 & 0.78 & 1.4 & 5460 & 3500 & 1.56 \\
\hline 3 & 2.0 & 1.46 & 0.7 & 2044 & 3247 & 0.62 \\
\hline 4 & 2.6 & 1.04 & 1.3 & 3515 & 2536 & 1.38 \\
\hline 6 & 3.2 & 0.31 & 2.6 & 2579 & 5100 & 0.50 \\
\hline 7 & 10 & 0.57 & 1.9 & 10830 & 5500 & 1.96 \\
\hline Mean \pm S.D & $4.54 \pm 2.78$ & $0.86 \pm 0.51$ & $1.52 \pm 0.81$ & $4708 \pm 3248$ & $4326 \pm 1441$ & $1.15 \pm 0.67$ \\
\hline
\end{tabular}

Table 10: Sediment carbon storage in fish ponds of Murshidabad district of West Bengal.

\begin{tabular}{|c|c|c|c|c|c|c|c|}
\hline District & Sample no. & $\begin{array}{l}\text { Sediment level } \\
(\mathrm{cm})\end{array}$ & $\begin{array}{l}\text { Dry bulk density(Mgl } \\
\left.\qquad \mathrm{m}^{3}\right)\end{array}$ & $\begin{array}{c}\text { Organic carbon } \\
(\%)\end{array}$ & $\begin{array}{c}\text { Carbonstorage/crop } \\
\text { (kg/ha) }\end{array}$ & $\begin{array}{l}\text { Production/ } \\
\text { Crop(kg/ha) }\end{array}$ & $\begin{array}{c}\text { C storage/ kg fish } \\
(\mathrm{kg})\end{array}$ \\
\hline \multirow{6}{*}{ Murshidabad } & 1 & 6.0 & 0.74 & 1.32 & 5860 & 4320 & 1.35 \\
\hline & 2 & 7.5 & 0.64 & 1.18 & 5664 & 7051 & 0.80 \\
\hline & 3 & 7.5 & 0.68 & 0.84 & 4284 & 7500 & 0.57 \\
\hline & 4 & 7.5 & 0.45 & 1.80 & 6075 & 8620 & 0.70 \\
\hline & 5 & 8.0 & 0.66 & 0.79 & 4171 & 4388 & 0.95 \\
\hline & Mean $\pm S D$ & $7.3 \pm 0.75$ & $0.63 \pm 0.10$ & $1.18 \pm 0.40$ & $5210 \pm 910$ & $6375 \pm 1932$ & $0.87 \pm 0.30$ \\
\hline
\end{tabular}

Parganas districts of West Bengal is shown in 11. The organic carbon content in the sediments of fish ponds was $1.38 \pm 0.59$ per cent, and the carbon storage was $5376 \pm 1597 \mathrm{~kg} \mathrm{C} / \mathrm{ha} /$ crop. The fish production was $4270 \pm 1008 \mathrm{~kg} / \mathrm{ha} / \mathrm{crop}$, and the C storage was $1.31 \pm 0.45 \mathrm{~kg} / \mathrm{kg}$ fish in 
Table 11: Sediment carbon storage in fish ponds of South and North 24 Paraganas districts of West Bengal.

\begin{tabular}{|c|c|c|c|c|c|c|}
\hline Sample no. & Sediment level $(\mathrm{cm})$ & $\begin{array}{l}\text { Dry bulk density } \\
\qquad\left(\mathrm{Mg} / \mathrm{m}^{3}\right)\end{array}$ & Organic carbon (\%) & $\begin{array}{c}\text { Carbon storagel } \\
\text { crop } \\
\text { (kg/ha) }\end{array}$ & $\begin{array}{c}\text { Production/ } \\
\text { crop } \\
\text { (kg/ha) }\end{array}$ & $\begin{array}{c}\text { C storage/ kg fish } \\
(\mathrm{kg})\end{array}$ \\
\hline 1 & 3.7 & 0.81 & 1.49 & 4465 & 4200 & 1.06 \\
\hline 2 & 4.2 & 0.95 & 1.08 & 4309 & 4800 & 0.89 \\
\hline 3 & 4.5 & 1.01 & 0.59 & 2681 & 5000 & 0.53 \\
\hline 4 & 5 & 1.01 & 0.68 & 3434 & 5550 & 0.61 \\
\hline 5 & 5 & 1.01 & 1.55 & 7827 & 4800 & 1.63 \\
\hline 6 & 4.7 & 0.64 & 2.42 & 7279 & 4366 & 1.66 \\
\hline 7 & 4.2 & 0.72 & 1.92 & 5806 & 5625 & 1.03 \\
\hline 8 & 4.5 & 0.51 & 2.45 & 5622 & 4742 & 1.18 \\
\hline 9 & 2.7 & 1.53 & 1.87 & 7724 & 5050 & 1.52 \\
\hline 10 & 4 & 1.56 & 1.07 & 6676 & 3375 & 1.97 \\
\hline 12 & 4.2 & 0.8 & 1.12 & 3763 & 2656 & 1.41 \\
\hline 13 & 4 & 1.56 & 0.87 & 5428 & 4000 & 1.35 \\
\hline 14 & 3.8 & 1.59 & 0.92 & 5558 & 2960 & 1.87 \\
\hline Mean $\pm S . D$ & $4.22 \pm 0.60$ & $1.03 \pm 0.37$ & $1.38 \pm 0.59$ & $5376 \pm 1597$ & $4270 \pm 1008$ & $1.31 \pm 0.45$ \\
\hline
\end{tabular}

Table 12: Proportions of combined humus $\mathrm{C}$ at some selected locations (\% soil organic carbon).

\begin{tabular}{|l|c|c|c|}
\hline \multicolumn{1}{|c|}{ Location } & $\begin{array}{c}\text { Loosely } \\
\text { combined } \\
\text { humus }\end{array}$ & $\begin{array}{c}\text { Stably combined } \\
\text { Humus }\end{array}$ & $\begin{array}{c}\text { Tightly combined } \\
\text { Humus }\end{array}$ \\
\hline $\begin{array}{l}\text { Habra I, North 24 } \\
\text { Parganas }\end{array}$ & 39 & 4 & 57 \\
\hline $\begin{array}{l}\text { Habra II, North 24 } \\
\text { Parganas }\end{array}$ & 40 & 4 & 56 \\
\hline $\begin{array}{l}\text { Barasat, North 24 } \\
\text { Parganas }\end{array}$ & 40 & 5 & 55 \\
\hline $\begin{array}{l}\text { Kharibari, North 24 } \\
\text { Parganas }\end{array}$ & 36 & 6 & 58 \\
\hline $\begin{array}{l}\text { Canning, South 24 } \\
\text { Parganas }\end{array}$ & 38 & 5 & 56 \\
\hline $\begin{array}{l}\text { Moyna I, East } \\
\text { Medinipur }\end{array}$ & 41 & 4 & 53 \\
\hline $\begin{array}{l}\text { Moyna II, East } \\
\text { Medinipur }\end{array}$ & & & 54 \\
\hline
\end{tabular}

the fish ponds of these districts.

The carbon storage with the fish production has presented in Figure 1. From the figure, it is evident that with an increase in fish production, the $\mathrm{C}$ storage decreased. The production per crop in the present study increased from $1815 \pm 376 \mathrm{~kg} / \mathrm{ha}$ to $8351 \pm 1882 \mathrm{~kg} /$ ha and accordingly, the $\mathrm{C}$ storage $/ \mathrm{kg}$ fish decreased from $1.44 \pm 0.73$ to $0.62 \pm 0.21$. This could be due to the fact that higher production utilized the $\mathrm{C}$ at a maximum level for their growth than that the same at lower production level.

In earlier study, [11] reported that the carbon sequestration capacity ranged from 442 to $1882 \mathrm{~kg} \mathrm{C} /$ ha with an average value of $1018 \pm 447 \mathrm{~kg} \mathrm{C} / \mathrm{ha}$ for 9 aquaculture ponds of one place. The present study conducted for different places under different management systems for 116 numbers of ponds.

The three types of combined humus carbon (loosely, stably and tightly combined humus carbon) are shown in Figure 2A, 2B, 2C and Table 12. The carbon contents of the loosely, stably and tightly combined humus ranged from 2.40 to $7.87 \mathrm{~g} / \mathrm{kg}$ (Figure 2A), 0.27 to
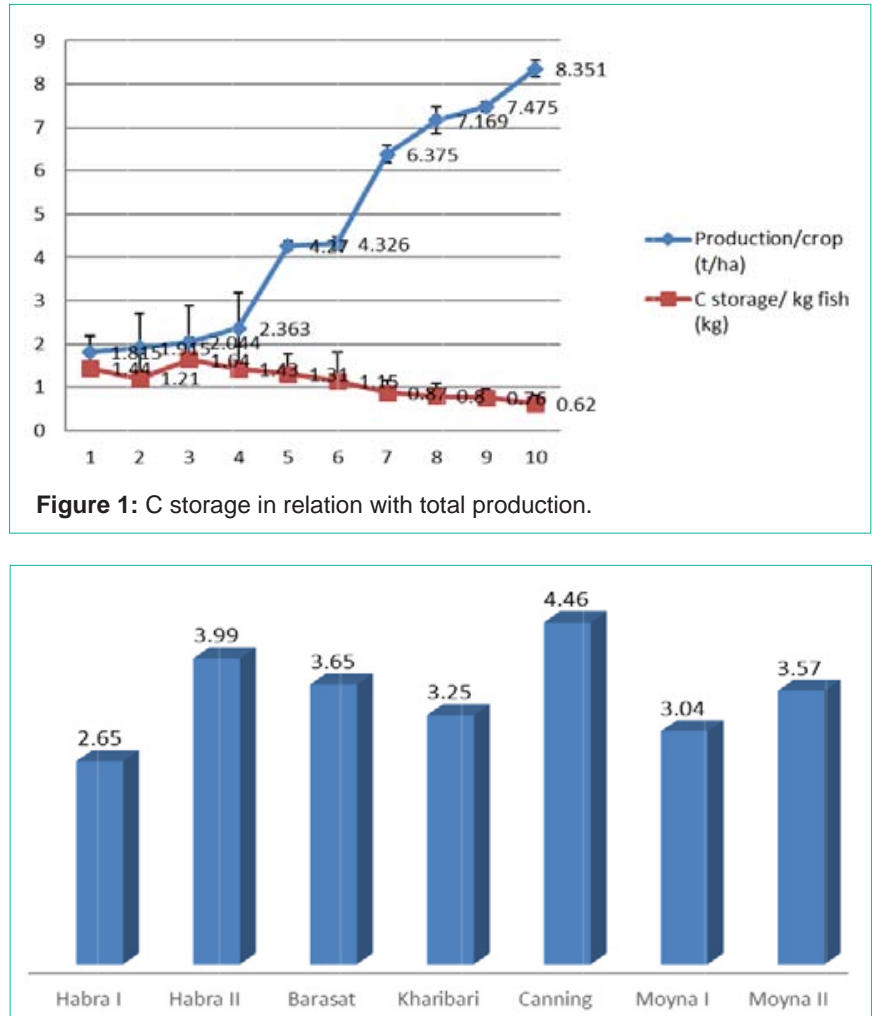

Figure 2A: $E_{465} / E_{665}$ of loosely combined humas.

$0.96 \mathrm{~g} / \mathrm{kg}$ (Figure 2B), and 3.30 to $11.02 \mathrm{~g} / \mathrm{kg}$ (Figure $2 \mathrm{C}$ ) respectively. The combined humus forms were arranged on the basis of $\mathrm{C}$ content in the following order: tightly> loosely> stably combined humus C. However, the proportion of the three combined humus $\mathrm{C}$ showed no significant differences among the different soils (Table 12). The loosely combined humus varied from 36 to 43 per cent, stably combined humus varied from 4 to 6 per cent, and tightly combined 


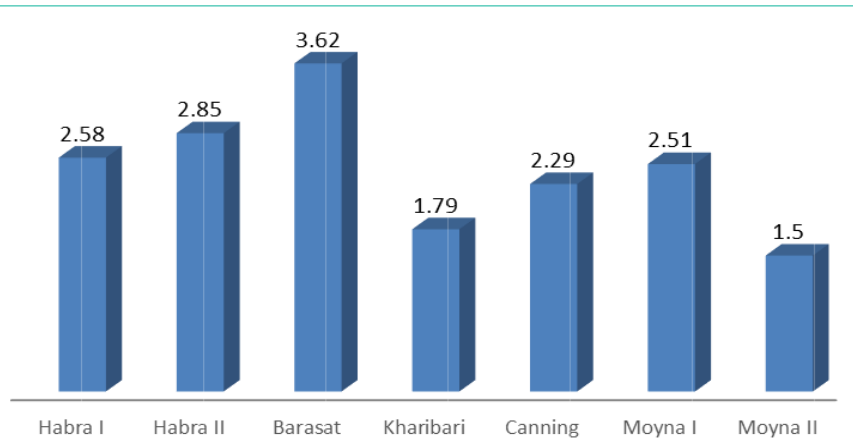

Figure 2B: $\mathrm{E}_{465} / \mathrm{E}_{665}$ of stably combined humus.

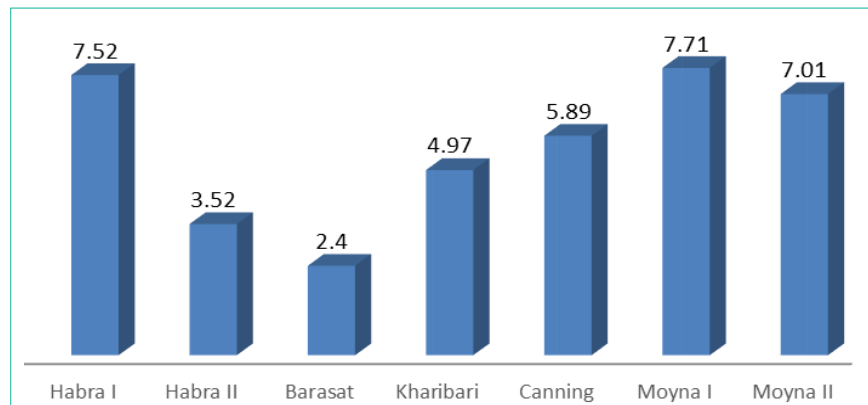

Figure 3A: Comparison of the C contents of loosely combined humus $\mathrm{C}$ ( $\mathrm{g}$ $\left.\mathrm{kg}^{-1}\right)$.

humus varied from 53 to 58 per cent, respectively. Among the three combined humus (loosely, stably and tightly combined humus C), loosely combined form constitute about 40 percent of the total soil organic carbon, and thus, carbon sequestration could be 60 percent of the total soil carbon storage.

The E465/E665 values of the loosely combined humus (2.60 to 4.46) were higher than that of the stably combined humus (1.50 to 3.62) (Figures 3A and 3B). Thus, the E465/E665 of loosely combined humus can be considered a more suitable index rather than that of the stably combined humus for identifying the aromaticity and humification degree of soil organic carbon. The E465/E665 ratio is related to the aromaticity and to the degree of condensation of the chain of aromatic carbons of the humic acids, and could be used as a humification index [12,13]. Low E465/E665 ratio reflects a high degree of condensation of these structures while high ratio means presence of large quantities of aliphatic structures and low quantities of condensed aromatic structures [14]. This ratio also is inversely related to the degree of aromaticity, particle size, molecular weight, and acidity [15].

\section{Conclusion}

From the present study it is evident that aquaculture ponds could play a vital role to counteract the emission of green house gases from the aquaculture practices by sequestering carbon in the sediments. Even if sometimes, the bottom sediments could remove from the pond to enhance the productivity, at least 60 per cent carbon storage will act as carbon sequester and it will not be able to come out in the atmosphere. Thus, more study is needed in this respect to generate more data so that carbon neutral aquaculture practices can be achieved.

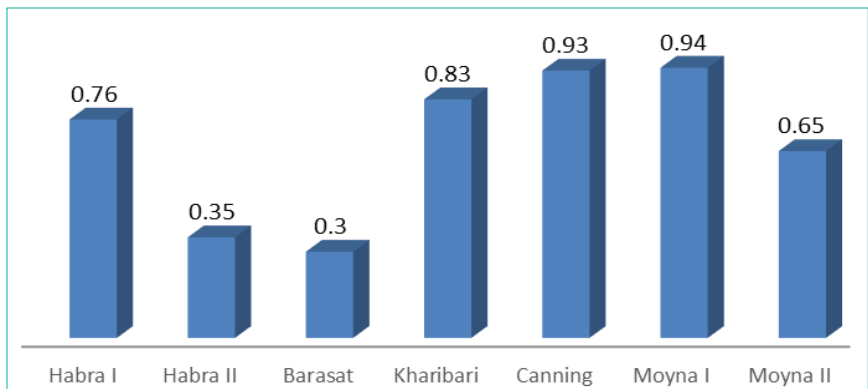

Figure 3B: Comparison of the $\mathrm{C}$ contents of stably combined humus $\mathrm{C}$ (g $\left.\mathrm{kg}^{-1}\right)$.

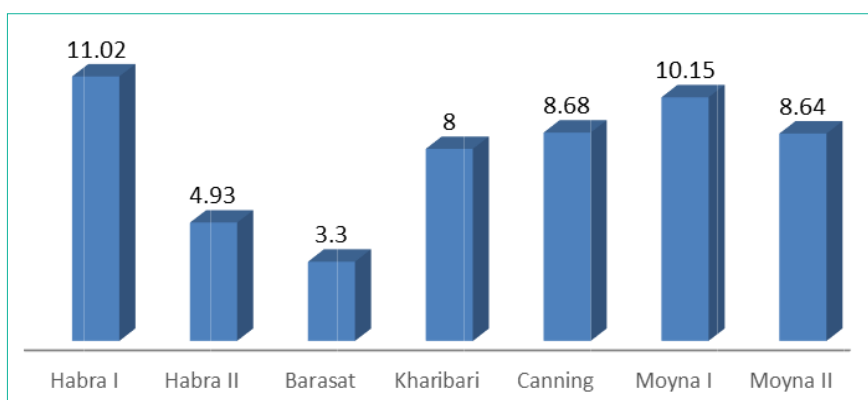

Figure 3C: Comparison of the $\mathrm{C}$ contents of tightly combined humus $\mathrm{C}$ ( $\mathrm{g}$ $\left.\mathrm{kg}^{-1}\right)$.

\section{Acknowledgement}

The funding of NICRA (National Innovation on Climate Resilient Agriculture) for conducting of the present investigation is gratefully acknowledged. We are also highly grateful to all the farmers for their immense help during our investigation.

\section{References}

1. IPCC (Intergovernmental Panel on Climate Change). Climate Change: Climate Change Impacts, Adaptation and Vulnerability. Working Group II, Geneva. 2007.

2. Xiaonan D, Xiaoke W, Lu F, Zhiyun O. Primary evaluation of carbon sequestration potential of wetlands in China. Acta Ecol Sin. 2008; 28: 463469.

3. Schlesinger WH. Carbon sequestration in soils. Science. 1999; 284: 2095.

4. Akselsson C, Berg B, Meentemeyer V, Westling O. Carbon sequestration rates in organic layers of boreal and temperate forest soils - Sweden as a case study. Global Ecol Biogeogr. 2015; 14: 77-84.

5. Walsh B. Greenhouse airlines: traveling by jet is a dirty business. As passenger load increases, enviros look for ways to cut back the carbon. Time Magazine. 2007; 169 .

6. Schrag DP. Preparing to capture carbon. Science. 2007; 315: 812-813.

7. Pacala S, Socolow R. Stabilization wedges: solving the climate problem for the next 50 years with current technologies. Science. 2004; 305: 968-972.

8. Eid EM, Shaltout $\mathrm{KH}$. Evaluation of carbon sequestration potentiality of Lake Burullus, Egypt to mitigate climate change. Egyptian Journal of Aquatic Research. 2013; 39: 31-38.

9. Lal R, Kimble JM, Follet RF, Cole CV. The potential of US cropland to sequester carbon and mitigate the greenhouse effect. Chelsea: Ann Arbor Press. 1998; 1: 128.

10. Ji H, Zhuang S, Zhu Z, Zhong Z. Soil Organic Carbon Pool and Its Chemical composition in Phyllostachy pubescens Forests at Two Altitudes in Jian-ou City, China. PLOS ONE. 2015; 10. 
11. Anikuttan KK, Adhikari S, Kavitha M, Jayasankar M. Carbon sequestration capacity of sediments, algae, and zooplankton from fresh water aquaculture ponds. Environ Monit Assess. 2016; 188: 422.

12. Kononova MM. Soil organic matter: Its nature, its role in soil formation and in soil fertility. Oxford: Pergamon. 1966.

13. Stevenson IL, Schnitzer M.Transmission. electron microscopy of extracted fulvic and humic acids. Soil Science. 1982; 133:179-185.
14. Chin YP, Aiken GR, Danielsen KM. Binding of pyrene to aquatic and commercial humic substances: the role of molecular weight and aromaticity. Environmental Science \& Technology. 1997; 31:1630-1635.

15. Uyguner CS, Hellriegel C, Otto W, Larive CK. Characterization of humic substances: Implications for trihalomethane formation. Analytical and bioanalytical chemistry. 2004; 378:1579-1586.
Austin J Environ Toxicol - Volume 5 Issue 1 - 2019

ISSN: 2472-372X | www.austinpublishing group.com

Adhikari et al. (C) All rights are reserved
Citation: Adhikari S, Mahanty D, Ikmail S, Sarkar S, Rathod R and Pillai BR. Carbon Storage in Sediments of Freshwater Fishponds of Odisha, Andhra Pradesh, and West Bengal, India. Austin J Environ Toxicol. 2019; 5(1): 1026. 